\title{
Effect Of Service Quality On Students' Intention To Provide Funding Support To Private Universities In Ghana: The Mediating Role of Students' Satisfaction
}

\author{
Stephen Banahene \\ Lecturer, Christian Service University College. School of Business \\ Jerry Jay Kraa \\ Lecturer, Christian Service University College, School of Business
}

Frank Frimpong Opuni

Accra Technical University, school of Business

\begin{abstract}
The study investigates the effect of service quality on students' intention to provide funding support to private universities in Ghana, the mediating role of students' satisfaction. 600 students were selected from 6 private universities of which 421 responses were useable representing $70.16 \%$ response rate. Purposive and convenience sampling techniques were adopted in selecting respondents. Questionnaire was used for data collection. Stata version 13 and IBM Statistical Package for Social Sciences version 20 were the software used in data analysis. The study made use of Structural Equation Model for data analysis. Confirmatory Factor Analysis was also used for data purification in achieving fit indices. The research found that HEdPERF positively and significantly affects students' satisfaction and their intention to provide funding support to Private University. Students satisfaction also positively and significantly impact on student's intention to provide funding support to Private University. As regards the mediation effect, customer satisfaction partially mediates the relationship between HEdPERF and intention to provide funding support to Private Universities. Managers and policy makers must take action to improve students' intention to provide funding support to Universities by promoting Reputation and Access issues in tertiary education.
\end{abstract}

Keywords: HEdPERF Scale, Service Quality, Intention to Provide Funding Support, Satisfaction

\section{INTRODUCTION}

Higher education funding has been one of the top priorities in many countries' policy agenda. In Ghana, the government has established Ghana Education Trust Fund (GETFUND) to provide funding support to the country's educational needs. In recent years, the number of universities, both public and private have increased with attended funding challenges. As an alternative to conventional Private University funding through students' fees, some Private Universities have developed funding models that have students as key stakeholders maintain the ultimate quality delivery. Most customers for that matter students have perception on the general quality level of a service comparing it to other available alternatives (1). The study beliefs that the relationship between students and the educational institutions they attended is more like a therapy than business. In the Ghanaian Private University population, there are businesspersons with established businesses and others occupying high political and social positions. These huge resources can be leveraged to the advantage of Private Universities in 
terms of their funding needs as they strife to meet students' needs. (2) is of the opinion that when higher quality product are delivered, there is a possibility of higher purchase intention hence the desire of private Universities to reap their benefits from student who pass through the institution. As regards public higher educational institutions, circumstances are changing as public funding for higher education is set to plummet. In Ghana, some civil society groups, individuals and Old Students Associations have join the effort improve education funding. It is still important that those who benefit the most from educational institutions should take huge interest to sustain the institutions. However, the interest of such beneficiaries does not happen by accident. Some factors can cause the interest to support academic institutions to happen the more. This student-driven approach to involve students in the funding model of Private Universities has the potential to find out the important constructs that affect intention to provide funding support to universities.

Intention to support university is an implied promise to one's self to provide any support to university during and after completing programme of study. This intention is substantially important because universities operate on different sources of funding to achieve their academic mandate. Intention to support further depicts the impression of existing students and alumni involvement in the affairs of universities. Different factors can influence students' intention to support university whiles studying and after completing programmes of study.

The higher education institutions are facing tremendous competitions in attracting full-fee paying students and thus, they are moving towards marketing approach to attracting and retaining students. Some studies have confirmed that the higher education sector can be considered as a marketplace and university education is a marketable service (3); (4). The implication from this is that universities can only be successful as long as their students (who are the primary customers) are offered with something that they wish to buy and at a quality they feel to be acceptable. Universities are realizing that they are business entities and like others they must compete for resources and students, both in the local and international markets (5). The researchers believe that educational institutions stand to gain higher return from students when such students successfully complete their programme of study and occupy rightful positions in the society. This means that good investment is required during the studentship experience to prepare to attract such a return. This study believes that service quality and students' satisfaction can be leveraged to attract higher return on higher education institutions' investment made in student.

\section{Service quality and intention of Customers}

\section{LITERATURE REVIEW}

Service quality is customer perception on the general quality level of a service with regard to the purpose of that service as compared to other alternatives (1). Service quality is usually based on key dimensions that consist of service specifications. The identification and measurement of service quality dimensions are useful, but researchers should not forget that service quality is a general perception. Service quality can be a good factor in assessing customers' intention to purchase or support education institution attended.(6) have concluded that if a product has a better quality, customer will be more inclined to purchase it. In addition, these authors have emphasized that product quality has a positive impact on customers' purchase intention. (7) has found that higher quality product creates higher purchase intention. (8) have investigated the effect of product quality on purchase intention. They collected 242 questionnaires and found that product quality has a significant and positive effect on purchase intention. This study also believes that there is academic interest in the study of service quality and students' intention to support academic institutions as the background of customer behavioural intentions. This study therefore hypothesized that; 


\section{$H_{1}$ : Service quality positively and significantly affects students' intention to provide funding support to Private University.}

The researchers are also of the opinion that service quality does not on its own lead to intention to provide funding support to higher education institutions, but can be affected by students' satisfaction. In this regard, the study again hypothesized that;

\section{$\mathrm{H}_{2}$ : Satisfaction mediates service quality and intention to provide funding support to Private University.}

\section{Service quality research in higher education}

Service quality research in higher education sector is now growing when compared to that of the commercial sector. Most of the quality models that are commonly practiced in the business world have been adapted and used in the education sector (9). (10) have reported that SERVQUAL scale is reliable and valid when it is applied to a particular classroom environment. This study further determines predictive ability of the SERVQUAL scale in a classroom environment using multiple regression analysis, where student satisfaction with the instructor is considered as a dependent variable and the five dimensions (assurance, empathy, responsiveness, tangibles, and reliability) are considered as independent variables. However, a number of studies have examined SERVQUAL scale in university environment and none of those studies are able to replicate five-factor structure of the SERVQUAL scale $(11,12) ;(13)$. Thus, conceptualization of the SERVQUAL scale on the (14)Expectancy-Disconfirmation Paradigm and its application to higher education environment is disputable. This is because the comparison of the gap and the performance-based approaches explains more of the variation in customer satisfaction and that the score of gap measurement and performance measurement show high degree of correlation (15) and (16). This has made SERVPERF an efficient and effective scale to find critical service attributes and measure quality.

(16) has developed Higher Education Performance (HEdPERF) scale, and the comparative results show that the HEdPERF scale captures more variance relative to that of the SERVPERF scale. The HEdPERF scale has non-academic aspects, academic aspects, reputation, access and programme issues dimensions. Though some authors have critised HEdPERF scale on the factor structure, face validity and its bias focus on administrative issues in the questionnaire (17) and (17), HEdPERF scale is useful to the measurement of higher education service quality.

\section{Service Quality and Satisfaction}

Service quality has grown over the years and has become a strategic force and important strategic tool for management researchers and industry practitioners. Many researchers have developed different service quality measurement scales for different sectors. It is not also difficult to witness a number of opinions on how to accurately measure service quality to understand its essential antecedents and consequences for improving quality to achieve competitive advantage that can impact on satisfaction and higher academic performance. In line with this thinking, (18) has emphasised that an essential part of any academic research is to review the academic literature with scholarly interest to make contribution to such an academic debate.

The predominant service quality scales used by many researchers and industry practitioners are the SERVQUAL (19) and SERVPERF (20) primarily because of their generic application. In the study by (21), SERVQUAL scale has been used or mentioned in 495 articles with the oldest article back from 1988 and the most recent article dates from 2016. However, the SERVQUAL and SERVPERF service quality performance indicators as adapted in higher education sector 
tend to measure activities rather than measures of the quality of students' educational experience ((22). To (15), the generality of the SERVQUAL and SERVPERF scales is still hazy when they are applied to service quality at higher education institutions. As a result, Abdullah has developed a new measurement scale called HEdPERF that was based on the SERVPERF scale, which considered the specific determinants of service quality in higher education. (23) have pointed out that, HEdPERF is the most developed scale in the literature to measure service quality in higher education. Since 2014, some researchers have used HEdPERF scale to measure service quality but they remain few when compared with SERVQUAL and SERVPERF (21). It is therefore interesting to undertake research on HEdPERF dimensions on students' intention to provide funding support to Private Universities to meet academic interest and managerial performance. In this same regard, the mediating role of students' satisfaction is necessary for consideration in terms of academic and managerial pursuit.

Most of the research works in higher education institutions have produced confirmation that service quality leads to students' satisfaction (24) and (25) but review of the available literature points to a number of inherent challenges in measuring service quality and customer satisfaction. Basically, most of the models of customer satisfaction often compare students' expectations to the observed service quality experience that are known as service quality gap. However, available evidence clarified the application of performance minus expectation has given positive effect to students' perceptions of service quality and with that, service quality directly affects students' satisfaction. Notwithstanding, higher education institutions provide high service quality in every part of its process in order to satisfy students who are the primary customers. This is so because satisfaction has been indicated as the customers' fulfillment response and service quality is noted as the key performance measurement for excellence in the education industry. (26) have indicated that the overall perceived service quality is an antecedent to satisfaction and it is also a major prerequisite for establishing and sustaining students' satisfaction and retention. (27) has suggested that future researchers should propose multiple-item scale to measure customer satisfaction, thereby lowering measurement errors and to improve scale reliability. (28) have pointed out that customer satisfaction should be considered as a multi-dimensional construct.

(29) modified the SERVQUAL measurement scale and empirically tested the health care service of Chiropractic Care to determine the relationship between service quality and patient satisfaction. The findings indicated that service quality should be treated as an antecedent of customer satisfaction. (30) studied customers of fast-food restaurant in America and Latin America and found that there is certain relationship between service quality and customer satisfaction based on different cultural background. (28) have found that service quality and customer satisfaction were highly related. In the work of (31), service quality is important factor for satisfaction among youngsters in Private Colleges in Faisalabad, Punjab and Pakistan. In their study, all the perspectives of service quality were found to be positively correlated but empathy showed negative relationship with service quality and customer satisfaction. It is appreciated that service quality and customer satisfaction have relationship to market share and customer retention (32). These studies point to the fact that service quality positively affects customer satisfaction. Therefore, the study has hypothesized that:

\section{$\mathrm{H}_{3}$ : Service quality positively and significantly affects customer satisfaction.}

\section{Methodology}

\section{METHODOLOGY AND MEASUREMENT OF CONSTRUCT}

This study is an applied research in terms of its objectives, it is quantitative in terms of data collection and analysis, and it is explanatory research design to establish causal relationships among service quality, satisfaction, and intention to provide funding support to Private 
University. The statistical community of this study consists of students in the private universities in the Ashanti Region of Ghana. Samples of 600 students were selected from six Private Universities with 100 from each institution. (33) has stated that, as small as of 30 samples is enough for successful statistical study if the characteristics of the respondents are homogenous in nature hence a sample of 600 is more than enough to be a representative of students from 6 private universities. Convenient and purposive sampling techniques were adopted in selecting respondent. The study used questionnaires in collecting primary data from the respondents. The questionnaires were closed ended on a 7-point Likert scale ranging from very strongly disagree (1) to very strongly agree (7) to the statements on the questionnaires. The researchers employed 6 additional field personnel who were trained to assist in data collection after the pilot testing was done. The study made use of IBM (20) Statistical Package for Social Science (SPSS) and Stata (version 13) in conducting the analysis. Confirmatory Factor Analysis (CFA) was done after which problematic indicators that loaded poorly were taken out. Structural Equation Model (SEM) was the main tool used to estimate the relationships. The study did control for programme of study, age of respondents and the institution attended in order to conserve statistical power.

\section{Measurement of Research Constructs}

In measuring variable used in the study, the HEdPERF variables were adapted from (15) research work and were amended to suit Ghanaian private university context. The HEdPERF dimensions are non-academic aspects, academic aspects, reputation, access and programme issues as used in the study. In all, 36 questions were developed but after the CFA purification, 19 variables were selected based on the fit indices. The students' satisfaction scale was adapted from (34)academic satisfaction scale. 12 questions were developed from the works of the author but after the CFA purification, 4 variables were selected based on the fit indices. The researchers developed the scale to measure intention to provide funding support to Private Universities. 6 questions were developed but after the CFA purification, 4 variables were selected based on the fit indices.

\section{Validity and Reliability Assessment}

To evaluate the reliability and validity of the HEdPERF dimensions, students' satisfaction and intention to provide funding support to Private Universities, CFA was run and refined using Stata 13 to show a good fit. The final CFA results show a good fit to the data. After purification, numerous items were removed from the models because they loaded poorly on the factor. The criterion used was 0.4 as advised by (35). Factor loadings for each construct were significant at $5 \%$ for the variables that supports convergent validity of the measures (35). Reliability was assessed using indicators of Convergent and Discriminant Validity, Composite Reliability, Average Variance Extracted (AVE), and Highest Shared Variance (HSV). All the AVE was greater as compared to the shared variances between constructs, meaning that satisfactory discriminant validity was achieved (36). In all the constructs, reliability assessment generated indices that were close to and greater than the recommended 0.70 cutoff (35) . By using (36) procedure, discriminant validity of each construct was assessed by examining whether the AVE for each construct was higher than the shared variances (i.e., squared correlations) of construct used. Discriminant validity is demonstrated for each construct for both samples, as the AVE for each construct is greater than the HSV between the constructs. Cronbach alpha was also used to assess internal consistency among the variables. Alpha values of close to and above 0.7 were achieved for each construct used. Tables 1 and 2 below show CFA results and fit indices respectively. 
Table 1: Validity and Reliability test using CFA

\begin{tabular}{|c|c|c|c|c|c|c|c|c|}
\hline \multicolumn{2}{|c|}{$\begin{array}{l}\text { Measures and Items } \\
\text { Retained }\end{array}$} & $\begin{array}{l}\text { Factor } \\
\text { Loadings }\end{array}$ & T values & $\begin{array}{l}\text { Cronbach's } \\
\text { Alpha }\end{array}$ & $\begin{array}{l}\text { Construct } \\
\text { Validity }\end{array}$ & $\begin{array}{l}\text { Highest } \\
\text { VIF }\end{array}$ & AVE & $\begin{array}{l}\text { Highest } \\
\text { Correlation }\end{array}$ \\
\hline \multirow{5}{*}{$\begin{array}{l}\text { Non-Academic } \\
\text { Aspect }\end{array}$} & Item 1 & .6908055 & 19.94 & \multirow{5}{*}{0.7837} & \multirow{5}{*}{0.792} & \multirow{5}{*}{1.59} & \multirow{5}{*}{0.652} & \multirow{5}{*}{0.5743} \\
\hline & Item 2 & .7275884 & 22.05 & & & & & \\
\hline & Item 3 & .6359725 & 17.05 & & & & & \\
\hline & Item 5 & .6077025 & 15.60 & & & & & \\
\hline & Item 8 & .5806738 & 14.44 & & & & & \\
\hline \multirow[t]{4}{*}{ Academic Aspect } & Item 1 & .5436257 & 11.56 & \multirow{4}{*}{0.6689} & \multirow{4}{*}{0.752} & \multirow{4}{*}{2.26} & \multirow{4}{*}{0.634} & \multirow{4}{*}{0.6013} \\
\hline & Item 5 & .5202072 & 10.73 & & & & & \\
\hline & Item 7 & .8139375 & 17.43 & & & & & \\
\hline & Item 8 & .4620713 & 9.59 & & & & & \\
\hline \multirow[t]{3}{*}{ Reputation } & Item 1 & .6839061 & 17.52 & \multirow{3}{*}{0.7235} & \multirow{3}{*}{0.760} & \multirow{3}{*}{2.07} & \multirow{3}{*}{0.727} & \multirow{3}{*}{0.6446} \\
\hline & Item 2 & .7811469 & 20.56 & & & & & \\
\hline & Item 3 & .6034162 & 14.37 & & & & & \\
\hline \multirow[t]{3}{*}{ Access } & Item 1 & .4918744 & 10.53 & \multirow{3}{*}{0.7067} & \multirow{3}{*}{0.831} & \multirow{3}{*}{1.45} & \multirow{3}{*}{0.729} & \multirow{3}{*}{0.5051} \\
\hline & Item 5 & .653702 & 13.98 & & & & & \\
\hline & Item 6 & .8909986 & 17.19 & & & & & \\
\hline \multirow{4}{*}{$\begin{array}{l}\text { Programme } \\
\text { Issues }\end{array}$} & Item 2 & .7504859 & 23.82 & \multirow{4}{*}{0.7990} & \multirow{4}{*}{0.802} & \multirow{4}{*}{1.99} & \multirow{4}{*}{0.704} & \multirow{4}{*}{0.5903} \\
\hline & Item 4 & .6878366 & 20.11 & & & & & \\
\hline & Item 5 & .7017046 & 20.80 & & & & & \\
\hline & Item 6 & .6867334 & 19.92 & & & & & \\
\hline Students & Item 6 & .6177804 & 15.90 & & & & & \\
\hline Satisfaction & Item 7 & .6426371 & 16.98 & & & & & \\
\hline & Item 11 & .7188582 & 20.97 & 0.7750 & 0.786 & 1.00 & 0.688 & 0.5675 \\
\hline & Item 12 & .7487615 & 22.48 & & & & & \\
\hline Intention to & Item 3 & .7197783 & 25.50 & & & & & \\
\hline $\begin{array}{l}\text { provide funding } \\
\text { support to }\end{array}$ & Item 4 & .8762163 & 42.24 & 0.8281 & 0.874 & 1.63 & 0.752 & 0.6207 \\
\hline Private & Item 5 & .824792 & 35.83 & & & & & \\
\hline Oniversity & Item 6 & .5448246 & 14.04 & & & & & \\
\hline
\end{tabular}

Source: Author Field work, 2016 
Banahene, S., Kraa, J. J., \& Opuni, F. F. (2018). Effect Of Service Quality On Students' Intention To Provide Funding Support To Private Universities In Ghana: The Mediating Role Of Students' Satisfaction. Advances in Social Sciences Research Journal, 5(5) 138-152.

Table 2: Measurement Invariance Tests (Fit Indices)

\begin{tabular}{|l|l|l|l|l|l|l|}
\hline Dimension/Construct & chi-square & $\begin{array}{l}\text { degrees of } \\
\text { freedom }\end{array}$ & p-value & RMSEA & CFI & SRMR \\
\hline Non-Academic & 6.04 & 5 & 0.3027 & 0.022 & 0.998 & 0.017 \\
\hline Academic & 1.68 & 2 & 0.4306 & 0.000 & 1.000 & 0.012 \\
\hline Reputation & 8.51 & 2 & 0.0142 & 0.089 & 0.979 & 0.026 \\
\hline Access & 0.00 & 0.00 & 0.00 & 0.000 & 1.000 & 0.000 \\
\hline Programme Issues & 2 & 3.36 & 0.1867 & 0.041 & 0.997 & 0.012 \\
\hline Students Satisfaction & 2 & 3.31 & 0.1908 & 0.040 & 0.997 & 0.013 \\
\hline $\begin{array}{l}\text { Intention to provide funding } \\
\text { support to Private University }\end{array}$ & 2 & 5.53 & 0.0629 & 0.065 & 0.995 & 0.013 \\
\hline
\end{tabular}

Notes: $\chi 2=$ Chi-square d.f.=Degree of freedom; $\chi 2 /$ d.f $=$ normed Chi-square; RMSEA=Root mean standard error of approximation; CFI=Comparative fit index; SRMR=Standardized mean square residual.

\section{Correlation matrix}

To check whether the strength of correlation among the variables will affect further statistical analysis; a multicollinearity test was run using the Pearson correlation statistics. For robustness, it is recommended that the correlation statistics should not exceed 0.7 (37). The correlation result shows positive and significant relationship among the variables. Correlation is significant at 0.01 . It can therefore be concluded that multicollinearity is not a serious threat in this study. The correction matrix is shown in table 3 below.

Table 3: Correlation Matrix

\begin{tabular}{|l|l|l|l|l|l|l|l|}
\hline & Non-A & Acad & Rep & Acc & PI & Sat & ISPU \\
\hline Non-A & 1 & & & & & & \\
\hline Acad & $0.5743^{* *}$ & 1 & & & & & \\
\hline Rep & $0.5002^{* *}$ & 0.6013 & 1 & & & & \\
\hline Acc & $0.3495^{*}$ & $0.4085^{* *}$ & $0.4788^{* *}$ & 1 & & & \\
\hline PI & $0.4705^{*}$ & $0.6207^{*}$ & $0.5944^{*}$ & $0.5051^{*}$ & 1 & & \\
\hline Sat & $0.3610^{* *}$ & $0.5643^{* *}$ & $0.6446^{* *}$ & $0.4254^{* *}$ & 0.5903 & 1 & \\
\hline ISPU & $0.3588^{* *}$ & $0.4976^{* *}$ & $0.5682^{* *}$ & $0.4312^{* *}$ & $0.4913^{* *}$ & $0.5342^{* *}$ & 1 \\
\hline
\end{tabular}

Non-A=Non Academic Performance Acad=Academic Performance Rep=Reputation of university Acc=Access PI=Programme Issues Sat=Students Satisfaction ISPU=Intention to provide funding support to Private Universities

\section{Demographic information}

\section{ANALYSIS AND DISCUSSION}

The work involved a sample of 412 respondents. A descriptive summary of the respondents shows that most of them are female (236) representing $57.3 \%$ and 176 representing $42.7 \%$ are males. Even though the males are more than the females in tertiary institution, more females participated in the study. Looking at the age distribution of the respondents, it is observed that the majority of the respondents, 220 (representing 53.4\%) fall within 20-30-year age bracket. This is followed by respondents whose ages are between 31-40 years (91) representing 22.1\%. A total of 69 respondents representing 16.7\% fell under 20 years and only one matured student is above 50 years. The general observation is that, most young and vibrant youths are 
devoting much time and effort to improve their education and hence working and attending school at the same time. On a whole, students studying business related courses such as accounting, marketing, human resource management, and procurement studies dominated student's enrolment in private universities in Ghana. 231 respondents are studying business related courses representing 56.1\% whiles 181 respondents representing 43.9 are pursuing other tertiary courses. Table 4 below shows demographic characteristics of the respondents.

Table 4: Demographic information

\begin{tabular}{lll}
\hline Variables & Frequency & Percentage (\%) \\
\hline Gender & 176 & 42.7 \\
Male & 236 & 57.3 \\
Female & & \\
Age distribution & 69 & 16.7 \\
under 20 years & 220 & 53.4 \\
20-30 years & 91 & 22.1 \\
31-40 years & 31 & 7.5 \\
41-50years & 1 & 0.2 \\
51 years and above & & \\
Programme of Study & 231 & 56.1 \\
Business Administration & 181 & 43.9 \\
Others course & &
\end{tabular}

\section{Relationship between HEdPERF dimensions, and Students' Satisfaction and Intention to provide funding support to Private Universities}

The study analysed the relationship between HEdPERF dimensions on one hand, and students' satisfaction and intention to provide funding support to Private Universities on the other. Four of the HEdPERF dimensions have positive relationship with students' satisfaction. These dimensions are Academic Aspect, Reputation, Access and Programme Issues. However, further analysis shows that Academic Aspect, Reputation and Programme Issues have positive and significant relationship with students' satisfaction. Non-Academic Aspect has negative relationship with students' satisfaction. Access has positive relationship with students' satisfaction but not statistically significant. These results imply that, Academic Aspect, Reputation and Programme Issues are statistically significant making a unique prediction to explaining students' satisfaction when the variance in the model is controlled for. However, improvements in Access can have positive impact on students' satisfaction but the effect is not statistically significant. The negative relationship between Non-Academic Aspect and students' satisfaction also means that an improvement in Non-Academic issues has dare consequences on students' satisfaction, though it is not statistically significant.

As regards HEdPERF dimensions (independent variables) relationship with intention to provide funding support to Private Universities (dependent variable), all the dimensions have positive relationship with the dependent variable. However, it is only Reputation and Access dimensions that are significant. This means that improvement in Reputation and Access dimensions can predict improvement in students' intention to provide funding support to Private Universities. Students' satisfaction also has positive relationship with intention to provide funding support to Private Universities with significant value. This also can explain the predictive influence of students' satisfaction on intention to provide funding support to Private Universities. The table 5 below shows the statistical information between HEdPERF dimensions, and students' satisfaction and intention to provide funding support to Private Universities. 
Table 5: HEdPERF dimensions' relationship with students' intention to provide funding support to Private Universities and students' satisfaction

\begin{tabular}{|l|l|l|l|l|l|}
\hline $\begin{array}{l}\text { HEdPERF } \\
\text { Dimension }\end{array}$ & Coefficient & OIM Std Err & $Z$ & P-Value & 95\% Conf. \\
\hline \multicolumn{7}{|c|}{ Students' Satisfaction } \\
\hline Non academic & -0.0773044 & 0.0465167 & -1.66 & 0.097 & -0.1684756 \\
\hline Academic & 0.1835234 & 0.0576548 & 3.18 & 0.001 & 0.070522 \\
\hline Reputation & 0.4137541 & 0.053665 & 7.71 & 0.000 & 0.3085726 \\
\hline Access & 0.063491 & 0.0394763 & 1.61 & 0.108 & -0.013881 \\
\hline $\begin{array}{l}\text { Programme } \\
\text { Issues }\end{array}$ & 0.2470384 & 0.0473694 & 5.22 & 0.000 & 0.154196 \\
\hline \multicolumn{7}{|l|}{} \\
\hline Non academic & 0.0147657 & 0.0499603 & 0.30 & \\
\hline Academic & 0.1161025 & 0.0624707 & 1.86 & 0.063 & 0.0831546 \\
\hline Reputation & 0.2578598 & 0.0614500 & 4.20 & 0.000 & 0.1374200 \\
\hline Access & 0.1263147 & 0.0423897 & 2.98 & 0.003 & -0.0432325 \\
\hline Prog. Issues & 0.079022 & 0.0523533 & 1.51 & 0.131 & -0.0235887 \\
\hline
\end{tabular}

\section{Relationship between HEdPERF, and Students' Satisfaction and Intention to provide funding support to Private Universities}

The findings of the study show that, HEdPERF as a measure of service quality at higher education favourably affects students' satisfaction and intention to provide funding support to Private Universities. HEdPERF has positive and significant effect on students' satisfaction $(\beta=0.8637773 ; p$-value=0.000). At the same time, HEdPERF has positive and significant effect on intention to provide funding support to Private Universities $(\beta=0.5642207 ; \rho$-value $=0.000)$. These findings have supported $\mathrm{H}_{1}$ and $\mathrm{H}_{3}$. As regards the relationship between student satisfaction and intention to provide funding support to Private Universities, the study found positive and significant relationship between the constructs $(\beta=0.241004 ; \rho$-value $=0.000)$. The table 6 below shows the statistical information on the relationship between HEdPERF, and students' satisfaction and intention to provide funding support to Private University.

Table 6: Relationship among HEdPERF, Students' Satisfaction and Intention to provide funding support to Private Universities

\begin{tabular}{|l|l|l|l|l|l|l|}
\hline $\begin{array}{c}\text { Independent } \\
\text { variable }\end{array}$ & Coef. & $\begin{array}{c}\text { OIM Std. } \\
\text { Err }\end{array}$ & $\mathbf{Z}$ & $\mathbf{P}>|\mathbf{z}|$ & $\mathbf{9 5 \%}$ Conf. & \multicolumn{1}{|c|}{ Dependent variable } \\
\hline HEdPERF & 0.8637773 & 0.0483939 & 17.85 & 0.000 & 0.7689271 & Student Satisfaction \\
\hline HEdPERF & 0.5642207 & 0.0657767 & 8.58 & 0.000 & 0.4353006 & $\begin{array}{l}\text { Intention to provide funding } \\
\text { support }\end{array}$ \\
\hline $\begin{array}{l}\text { Students' } \\
\text { Satisfaction }\end{array}$ & 0.241004 & 0.050286 & 4.79 & 0.000 & 0.1424453 & $\begin{array}{l}\text { Intention to provide funding } \\
\text { support to Private Universities }\end{array}$ \\
\hline
\end{tabular}

These findings from Ghana's higher education context show that service quality positively and significantly affect students' satisfaction. This means that when service quality improves students' satisfaction goes up. This finding support the works of (31) on students in Private Colleges in Faisalabad showing positive relationship between service quality and student satisfaction. The findings on HEdPERF relationship with intention to provide funding support to Private Universities also support the works of (6) , (7) and (8) who concluded that service quality affect customers' purchase and re-purchase intention of firms services. 


\section{Mediation role of students' satisfaction between HEdPERF and Students' intention to provide funding support to Private Universities}

Mediation seeks to identify and explicate the mechanism that underlies an observed relationship between an independent variable (HEdPERF) and a dependent variable (intention to provide funding support to Private Universities) via the inclusion of a third explanatory variable, known as the mediator (students' satisfaction). Rather than hypothesizing a direct causal relationship between HEdPERF and students' satisfaction a mediation model hypothesizes that the HEdPERF causes the mediator variable (students' satisfaction), which in turn causes the dependent variables (intention to provide funding support to Private University). Specifically, this study looked at whether students' satisfaction performs any mediating role in the relationship between HEdPERF and intention to provide funding support to Private University. (38) believed that, there are many ways that can be used to test hypotheses with respect to establishing mediation. One of the commonly method that is adopted has to do with causal steps strategy, propounded by (11). Thus the investigator estimates the paths of the model, using Ordinary Least Square (OLS) regression or SEM, that ascertain the degree to which many criteria are met. (11) proposed some important but not sufficient conditions which must be met in order to claim mediation is happening. For mediation conditions to exist the independent variable should significantly relate to the mediator and the mediator should also significantly related to the dependent variable. The relationship between the independent variable and dependable variable diminishes when the mediator is in the model. That means that, each of the constructs should show proof of a nonzero monotonic association with each other, but the relationship of the independent variable and dependent variable must decrease substantially upon adding the mediator as a predictor of the dependent variable (39). The study expects students' satisfaction to mediate between HEdPERF and students' intention to provide funding support to Private Universities.

Examining the standard estimates of the mediation model, it is observed that the direct paths from HEdPERF to students' satisfaction is positive and statistically significant $(\beta=0.5642207$; $\rho$-value $=0.000$ ). The indirect path of HEdPERF through students' satisfaction to intention to provide funding support to Private Universities is also positive and statistically significant $(\beta=0.2081738 ; \rho$-value $=0.000)$. The total effect for HEdPERF on intention to provide funding support to Private Universities is also positive and statistically significant $(\beta=0.7723945 ; \rho$ value $=0.000$ ). Base on the assumption by (40) students' satisfaction partially mediate the relationships between HEdPERF and students' intention to provide funding support to Private Universities. This finding partially supports $\mathrm{H}_{2}$.

Further analysis on HEdPERF dimensions relationship with students' intention to provide funding support to Private Universities via students' satisfaction reveals useful insight. The direct paths from Non-Academic aspects to students' intention to provide funding support to Private Universities is positive but not statistically significant $(\beta=0.0147657 ; \rho$-value $=0.768)$. The indirect path of Non-Academic Aspects through students' satisfaction to intention to provide funding support to Private Universities is negative and not statistically significant $(\beta=$ $0.0154542 ; \rho$-value $=0.000$ ). The total effect for Non-Academic Aspects on intention to provide funding support to Private Universities is also negative and not statistically significant $(\beta=-$ $0.0006885 ; \rho$-value $=0.000)$. Base on the assumption by (11) students' satisfaction does not mediate the relationships between Non-Academic Aspects and students' intention to provide funding support to Private Universities.

The direct paths from Academic aspects to students' intention to provide funding support to Private Universities is positive but not statistically significant $(\beta=0.1161025 ; \rho$-value $=0.768)$. The indirect path of Academic Aspects through students' satisfaction to intention to provide 
funding support to Private Universities is positive and statistically significant $(\beta=0.0366888 ; \rho$ value $=0.000$ ). The total effect for Academic Aspects on intention to provide funding support to Private Universities is positive and statistically significant $(\beta=0.1527913 ; \rho$-value $=0.000)$. Base on the assumption by (11) students' satisfaction fully mediates the relationships between Academic Aspects and students' intention to provide funding support to Private Universities.

The direct paths from Reputation to students' intention to provide funding support to Private Universities is positive and statistically significant $(\beta=0.2578598 ; \rho$-value $=0.768)$. The indirect path of Reputation through students' satisfaction to intention to provide funding support to Private Universities is positive and statistically significant $(\beta=0-0.082715 ; \rho$-value $=0.000)$. The total effect for Reputation on intention to provide funding support to Private Universities is also positive and statistically significant $(\beta=-0.3405748 ; \rho$-value $=0.000)$. Base on the assumption by (11) students' satisfaction partially mediates the relationships between Reputation and students' intention to provide funding support to Private Universities.

The direct paths from Access to students' intention to provide funding support to Private Universities is positive and statistically significant $(\beta=0.1263147 ; \rho$-value $=0.768)$. The indirect path of Access through students' satisfaction to intention to provide funding support to Private Universities is positive but not statistically significant $(\beta=0-0.0126927 ; \rho$-value $=0.000)$. The total effect for Access on intention to provide funding support to Private Universities is also positive and statistically significant $(\beta=-0.1390074 ; \rho$-value $=0.000)$. Base on the assumption by (11) students' satisfaction does not mediate the relationships between Access and students' intention to provide funding support to Private Universities.

The direct paths from Programme Issues to students' intention to provide funding support to Private Universities is positive but not statistically significant $(\beta=0.079022 ; \rho$-value $=0.768)$. The indirect path of Programme Issues through students' satisfaction to intention to provide funding support to Private Universities is positive and statistically significant ( $\beta=0-0.0493863$; $\rho$-value $=0.000$ ). The total effect for Programme Issues on intention to provide funding support to Private Universities is also positive and statistically significant $(\beta=-0.1284083 ; \rho$ value $=0.000)$. Base on the assumption by (11) students' satisfaction fully mediates the relationships between Programme Issues and students' intention to provide funding support to Private Universities.

The implication is that, HEdPERF as a measure of service quality on its own can impact positively and significantly on students' intention to provide funding support to Private Universities. As regards using HEdPERF to promote students' intention to provide funding support to Private Universities, Access has the potential to strike students to provide the support because there is no mediation and has statistical significance. However, Reputation can also be used to promote students' intention to provide funding support to Private Universities. There is also another way that students' intention to provide funding support to Private Universities can be enhanced through students' satisfaction. The study found that Academic Aspects and Programme Issues can be used to promote the mediation role of students' satisfaction due to their fully mediation role revealed by the study. Table 7 shows direct, indirect and total effect of HEdPERF and HEdPERF Dimensions on students' intention to provide funding support to Private Universities via students' satisfaction. 
Table 7: Mediation role of Student Satisfaction

\begin{tabular}{|c|c|c|c|c|}
\hline Path & $\begin{array}{l}\text { Direct Effect } \\
\text { (D) }\end{array}$ & Indirect Effect (I) & $\begin{array}{l}\text { Total Effect } \\
(\mathrm{D}+\mathrm{I})\end{array}$ & $\begin{array}{c}\text { Form of } \\
\text { Mediation }\end{array}$ \\
\hline \multicolumn{5}{|c|}{ Between HEdPERF Dimensions and Intention to provide funding support to Private Universities } \\
\hline $\mathrm{NAA} \longrightarrow \mathrm{SS} \rightarrow$ ISPU & 0.0147657 & -0.0154542 & -0.0006885 & No Mediation \\
\hline$\longrightarrow \mathrm{SS} \longrightarrow \mathrm{PPU}$ & 0.1161025 & $0.0366888^{* *}$ & $0.1527913^{* *}$ & Full Mediation \\
\hline $\mathrm{REP} \longrightarrow \mathrm{SS} \longrightarrow \mathrm{SPU}$ & $0.2578598^{* *}$ & $0.0827150^{* *}$ & $0.3405748^{* *}$ & $\begin{array}{l}\text { Partial } \\
\text { Mediation }\end{array}$ \\
\hline$\longrightarrow S P U$ & $0.1263147^{* *}$ & 0.0126927 & $0.1390074^{* *}$ & No Mediation \\
\hline PROI $\longrightarrow S$ & 0.079022 & $0.0493863^{* *}$ & $0.1284083^{* *}$ & Full Mediation \\
\hline \multicolumn{5}{|c|}{ Between. HEdPERF and Intention to provide funding support to Private Universities } \\
\hline HEdPERF $\stackrel{S S \text { ISPU } \longrightarrow}{\longrightarrow}$ & $0.5642207^{* *}$ & $0.2081738^{* *}$ & $0.7723945^{* *}$ & $\begin{array}{l}\text { Partial } \\
\text { Mediation }\end{array}$ \\
\hline
\end{tabular}

Note: $\mathrm{NAA}=$ Non-Academic Aspect; $\mathrm{AA}=$ Academic Aspect; REP=Reputation; $\mathrm{ACC}=\mathrm{Access}$; PROI=Programme Issues; SS=Students' Satisfaction; ISUP= Intention to provide funding support to Private Universities; $\mathrm{P}^{* *}$ Statistical Significance

\section{Summary of Hypothesized Construct}

HEdPERF which is a measure of service quality positively and significantly predict both students' satisfaction and students' intention to provide funding support to Private Universities. Students' satisfaction partially mediates the relationship between HEdPERF and students' intention to provide funding support to Private Universities. This implies that, HEdPERF on its own can impact on students' intention to provide funding support to Private Universities. However, if students' satisfaction is improved, students' intention to provide funding support to Private Universities can also be realized. Table 8 presents summary of the hypothesized constructs.

Table 8: Summary of hypothesized construct

\begin{tabular}{|l|l|l|}
\hline \multicolumn{2}{|c|}{ Hypothesis } & Status \\
\hline $\mathrm{H}_{1}$ & $\begin{array}{l}\text { Service quality positively and significantly affects students' intention to provide } \\
\text { funding support to Private University }\end{array}$ & Supported \\
\hline $\mathrm{H}_{2}$ & $\begin{array}{l}\text { Customer satisfaction mediates service quality and intention to provide funding } \\
\text { support to Private Universities }\end{array}$ & $\begin{array}{l}\text { Partially } \\
\text { Mediated }\end{array}$ \\
\hline $\mathrm{H}_{3}$ & Service quality positively and significantly affects student's satisfaction. & Supported \\
\hline
\end{tabular}

\section{CONCLUSIONS}

This study has the objective to investigate HEdPERF effects on intention to provide funding support to Private Universities, and the mediating role of satisfaction. To achieve this objective, the research appraised all the measurement scales of the said constructs to determine their measurement value in the study context for theory and managerial practices. The study found that out of the HEdPERF 36 variables as developed by Abdullah (2005), 19 variables adequately measure service quality at Ghanaian private higher education sector. The study revealed that, the number of items under each of the 5 dimension of HEdPERF was reduced. The non-academic aspect dimension items were reduced from 8 to 5 . The rest of the reductions were academic aspect from 8 to 4 , reputation from 7 to 3 , access from 7 to 3 , and programme issues from 6 to 4. Three dimensions (academic aspects, reputation and programme issues) have positive and significant relationships with students' satisfaction. Reputation and Access also have positive and significant relationship with students' intention to provide funding support to Private Universities. On the contrally, Non Academic Aspect dimension has negative and no significant relationships with students' satisfaction. But the Non-Academic Aspect has positive but no significant relationship with students' intention to provide funding support to Private Universities. Academic Aspect and Programme Issues have positive but no significant effect on students' intention to provide funding support to Private Universities. As regards the mediation effect, students' satisfaction partially mediates between HEdPERF and students' 
intention to provide funding support to Private Universities. This means that service quality effect on students' intention to provide funding support to Private Universities can be achieved with or without students' satisfaction.

\section{MANAGERIAL AND POLICY IMPLICATIONS}

The major conclusion from our study is that, for predictive purposes managers of higher education sector should focus on academic aspect, reputation, and programme issues to achieve students' satisfaction. This study has revealed that Non-Academic Aspect has negative relationship with students' satisfaction and this need to be considered in their actions to improve students' satisfaction. In addition, managers and policy makers can take action to improve students' intention to provide funding support to Private Universities by promoting Reputation and Access issues. The direct effect of HEdPERF on students' intention to provide funding support to Private Universities is greater $(\beta=0.5642207 ; \rho$-value $=0.000)$ than the indirect effect $(\beta=0.2081738 ; \rho=0.000)$. This means that managers of higher education can achieve better students' intention to provide funding support to Private Universities through service quality so as to enhance satisfaction before improving students' intention to provide funding support to Private Universities.

\section{DIRECTION TO FUTURE STUDIES WITH LIMITATIONS}

This research has provided additional insight into HEdPERF, students' satisfaction, and students' intention to provide funding support to Private Universities. The negative relationship between Non-Academic Aspect dimension and students' satisfaction should be further investigated. The partial mediation role of students' satisfaction on the relationship between HEdPERF and students' intention to provide funding support to Private Universities needs further research in different higher education context. Notwithstanding the new insight into HEdPERF, students' satisfaction, and intention to provide funding support to Private Universities, users of this study should do so in context although considerable evidence of relative efficacy has been found in the modified constructs. The present study is limited to Ghanaian Private Universities based in Kumasi and the assertion needs to be validated by further studies in different University settings.

\section{Reference}

Keller KL, Parameswaran M, Jacob I. Strategic brand management: Building, measuring, and managing brand equity: Pearson Education India; 2011.

Tsiotsou R. The role of perceived product quality and overall satisfaction on purchase intentions. International journal of consumer studies. 2006;30(2):207-17.

Brown RM, Mazzarol TW. The importance of institutional image to student satisfaction and loyalty within higher education. Higher Education. 2009;58(1):81-95.

Zemsky R, Wegner GR, Massy WF. Remaking the American university: Market-smart and mission-centered: Rutgers University Press; 2005.

Paswan AK, Ganesh G. Higher education institutions: Satisfaction and loyalty among international students. Journal of Marketing for Higher Education. 2009;19(1):65-84.

Chi HK, Yeh HR, Huang MW. The Influences of advertising endorser, brand image, brand equity, price promotion on purchase intention: The mediating effect of advertising endorser. The Journal of Global Business Management. 2009;5(1):224-33.

Tsiotsou R. Perceived quality levels and their relation to involvement, satisfaction, and purchase intentions. Marketing Bulletin. 2005;16(4):1-10.

Jalilvand MR, Samiei N, Mahdavinia SH. The effect of brand equity components on purchase intention: An application of Aaker's model in the automobile industry. International business and management. 2011;2(2):14958. 
Chua C, editor Perception of quality in higher education. Proceedings of the Australian universities quality forum; 2004: Australian University Quality Agency Melbourne.

Stodnick M, Rogers P. Using SERVQUAL to measure the quality of the classroom experience. Decision Sciences Journal of Innovative Education. 2008;6(1):115-33.

Baron RM, Kenny DA. The moderator-mediator variable distinction in social psychological research: Conceptual, strategic, and statistical considerations. Journal of personality and social psychology. 1986;51(6):1173.

Oldfield BM, Baron S. Student perceptions of service quality in a UK university business and management faculty. Quality Assurance in education. 2000;8(2):85-95.

Jain R, Sinha G, Sahney S. Conceptualizing service quality in higher education. Asian Journal on Quality. 2011;12(3):296-314.

Oliver RL. A cognitive model of the antecedents and consequences of satisfaction decisions. Journal of marketing research. 1980:460-9.

Abdullah F. HEdPERF versus SERVPERF: The quest for ideal measuring instrument of service quality in higher education sector. Quality Assurance in education. 2005;13(4):305-28.

Li RY, Kaye M. A case study for comparing two service quality measurement approaches in the context of teaching in higher education. Quality in Higher Education. 1998;4(2):103-13.

Sultan P, Yin Wong H. Service quality in higher education-a review and research agenda. International Journal of Quality and Service Sciences. 2010;2(2):259-72.

Croom S. Introduction to research methodology in operations management. Researching operations management: Routledge; 2010. p. 56-97.

Parasuraman A, Zeithaml V, Berry L. SERVQUAL: a multiple-item scale for measuring consumer perceptions of service quality. Retailing: critical concepts. 2002;64(1):140.

Cronin Jr JJ, Taylor SA. Measuring service quality: a reexamination and extension. The journal of marketing. 1992:55-68.

Silva DS, Moraes GHSMd, Makiya IK, Cesar FIG. Measurement of perceived service quality in higher education institutions: A review of HEdPERF scale use. Quality Assurance in Education. 2017;25(4):415-39.

Soutar G, McNeil M. Measuring service quality in a tertiary institution. Journal of Educational Administration. 1996;34(1):72-82.

Icli G, Anil N. The HEDQUAL scale: A new measurement scale of service quality for MBA programs in higher education. South African Journal of Business Management. 2014;45(3):31-43.

Anderson EA. Measuring service quality at a university health clinic. International Journal of Health Care Quality Assurance. 1995;8(2):32-7.

Athanassopoulos A, Gounaris S, Stathakopoulos V. Behavioural responses to customer satisfaction: an empirical study. European journal of marketing. 2001;35(5/6):687-707.

Raghavan S, Ganesh R. Addressing Service Quality to Increase Students' Satisfaction and Retention in Malaysian Private Higher Education Institutions. American Journal of Economics. 2015;5(2):243-50.

Westbrook RA. A rating scale for measuring product/service satisfaction. The Journal of Marketing. 1980:68-72.

Sureshchandar G, Rajendran C, Anantharaman R. The relationship between service quality and customer satisfaction-a factor specific approach. Journal of services marketing. 2002;16(4):363-79.

De Ruyter K, Bloemer J, Peeters P. Merging service quality and service satisfaction. An empirical test of an integrative model. Journal of economic psychology. 1997;18(4):387-406.

Brady MK, Robertson CJ. Searching for a consensus on the antecedent role of service quality and satisfaction: an exploratory cross-national study. Journal of Business research. 2001;51(1):53-60.

Bharwana TK, Bashir M, Mohsin M. Impact of service quality on customers' satisfaction: A study from service sector especially private colleges of Faisalabad, Punjab, Pakistan. International Journal of Scientific and Research Publications. 2013;3(5):1-7.

Rego LL, Morgan NA, Fornell C. Reexamining the market share-customer satisfaction relationship. Journal of Marketing. 2013;77(5):1-20.

Stutely R. Numbers guide: Bloomberg Press; 2003. 
Athiyaman A. Linking student satisfaction and service quality perceptions: the case of university education. European journal of marketing. 1997;31(7):528-40.

Bagozzi RP, Yi Y. Specification, evaluation, and interpretation of structural equation models. Journal of the academy of marketing science. 2012;40(1):8-34.

Fornell C, Larcker DF. Structural equation models with unobservable variables and measurement error: Algebra and statistics. Journal of marketing research. 1981:382-8.

Hair JF, Black WC, Babin BJ, Anderson RE, Tatham RL. Multivariate data analysis: Prentice hall Upper Saddle River, NJ; 1998.

MacKinnon DP, Goldberg L, Clarke GN, Elliot DL, Cheong J, Lapin A, et al. Mediating mechanisms in a program to reduce intentions to use anabolic steroids and improve exercise self-efficacy and dietary behavior. Prevention Science. 2001;2(1):15-28.

Bolger N. Data analysis in social psychology. Handbook of social psychology. 1998;1:233-65.

Kenny D, Kashy D, Bolger N. Data analysis in social psychology (In D. Gilbert, S. Fiske, \& G. Lindzey (Eds.). The handbook of social psychology (Vol. 1, pp. 233-265). Boston, MA: McGraw-Hill; 1998. 